\title{
Application of Light Expanded Clay Aggregate as Replacement of Coarse Aggregate in Concrete Pavement
}

\author{
Pavithra $\mathrm{A}^{1}$, Jerosia De Rose $\mathrm{D}^{2}$, \\ ${ }^{I}$ Assistant Professor, Department of Civil Engineering, SRM Easwari Engineering College, Chennai \\ ${ }^{2}$ Assistant Professor, Department of Civil Engineering, SRM Easwari Engineering College, Chennai \\ Tamil Nadu, India \\ *Corresponding author E-mail:pavithra.r.prisha@gmail.com.
}

\begin{abstract}
The main aim of this project is to develop a light weight concrete (LWC) by replacing the coarse aggregate with light weight expanded clay aggregate. The damage caused in LWC is less significant than conventional concrete and therefore the maintenance cost is also reduced. In order to understand the effect of light weight aggregate in concrete, conventional concrete of strength $30 \mathrm{MPa}$ was designed with the density of $2400 \mathrm{~kg} / \mathrm{m}^{3}$. Then the natural coarse aggregates were replaced by clay aggregates and light weight concrete mix of density $1800 \mathrm{~kg} / \mathrm{m}^{3}$ was designed to meet the desired strength requirement. As the density of the concrete tends to be lowered, the strength of the concrete may also tend to decrease. Hence suitable chemical and mineral admixture is to be incorporated in addition to significant water reduction to meet the strength requirement. Cement content kept constant in both the cases. The details of mechanical properties and durability properties of conventional and light weight concrete are reported in this paper.
\end{abstract}

Keywords: LWC, M30 grade, chemical admixture, Compression Strength, Split Tensile Strength, Flexure Strength, RCPT, WPT

\section{Introduction}

Light weight concrete can be defined as a type of concrete which includes an expanding agent in that it increases the volume of the mixture while giving additional qualities such as nailibility and lessened the dead weight. It is lighter than the conventional concrete with a dry density of $300 \mathrm{~kg} / \mathrm{m}^{3}$ up to $1840 \mathrm{~kg} / \mathrm{m}^{3} ; 87$ to $23 \%$ lighter.LWAC is manufactured by using different kinds of lightweight aggregates, available in nature or artificially produced, so that the properties of LWAC depend on the properties of the particular lightweight aggregate being used. Natural lightweight aggregate sources can be found in regions characterized by volcanic activity, where porous rocks (known as pumices) are available. Artificial lightweight aggregates (like the expanded clay obtained by thermal treatment of argillaceous materials) are produced in many countries, the raw materials being very common. They may exhibit higher resistance than natural lightweight aggregates, but this favorable result implies a greater production cost. Clays has formed a mass with full of gas bubbles when it is heated and called "expanded clay". It has the highest compressive strength among lightweight building materials. The most important characteristics of expanded clay are being a light material, having a high compressive strength and providing heat isolation. Earthquake damage effects have direct relation with building weights. Earthquake risks can be decreased with lightening buildings static load. In all light weight concrete mixes it is intended to use supplementary cementitious materials to improve the strength and durability parameters. However mixes containing normal aggregates tend to show increased strength due to higher crushing value of coarse aggregates. In order to achieve strength similar to normal concrete increase in cement content is considered or reduc- tion in w/c ratio by incorporating suitable chemical admixture is considered.

According to ACI 318 building code for structural concrete defines light weight concrete as concrete containing light weight aggregate with an equilibrium density between $1440-1840 \mathrm{~kg} / \mathrm{m} 3$ and the compressive strength $>17 \mathrm{MPa}$ which corresponds to $20 \mathrm{MPa}$ for cubical specimens. Structural lightweight concrete has many and varied applications, including multistory building frames and floors, curtain walls, shell roofs, folded plates, bridge decks and girders, prestressed or precast elements of all types, and concrete pavements. In many cases, the architectural expression of form, combined with functional design, is achieved more readily with structural lightweight concrete than with any other medium. Since the properties and the performance of the light weight concrete are dependent on the type of light weight aggregate (LWA) used and the producer, both are important for achieving the project objective. Light weight aggregate are of two types. They are clay aggregates and fly ash based (sintered) aggregate. Clay aggregates are lighter than fly ash aggregates. Hence for considerable reduction in density of concrete, clay aggregate is preferred. LWC is also used in cold climatic zones as insulating materials in pavements especially in Norway and part of European countries. Traditionally road construction materials like gravel and crushed rock have very low insulation capacity and quite thick layers are needed to avoid frost penetration. Light weight expanded clay aggregate (LWA) is a promising alternative because of its good insulation properties. LWC can also be used in pavement repairs. Generally pavements are cured with water superficially and it dries up very fast. Hence free curing is necessitated. However presence of LWA which has large absorbing capacity retains the water and releases when the hydration proceeds and it is more beneficial 
when supplementary cementitious materials are used. Further due to lighter in weight no need to have extra support for formwork.

\section{Scope}

* Design of M30 grade normal concrete (NC).

* Design of LWC using light weight clay aggregate (LECA).

* Study on mechanical properties of NC and LWC.I

* Durabiliity study on NC and LWC.

\section{Raw Materials}

The raw materials used in light weight concrete is the light weight aggregate of size 2 to $8 \mathrm{~mm}$ and rest with the same materials as used in normal concrete. The light weight aggregate used in this experiment is clay based aggregate of density $540-600 \mathrm{~kg} / \mathrm{m} 3$. It is an indigenously manufactured aggregate supplied from Rajasthan. However the normal natural aggregate used in normal concrete was obtained from a local quarry. It is granite aggregate with specific gravity of 1.59. The light weight aggregate and the natural aggregate used in their respective concrete are shown in fig. 1 and fig. 2 respectively.

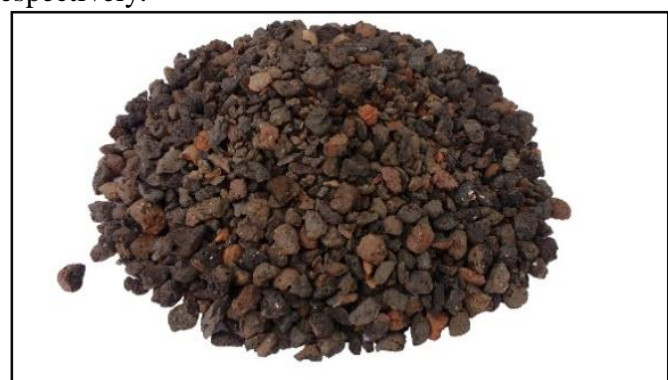

Fig 1: Light weight aggregate

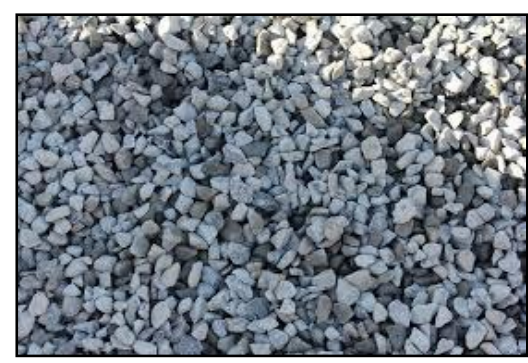

Fig 2: Natural aggregate

The cement used was OPC53 grade cement and was tested for its physical properties as per IS: 4031. The manufactured sand (Msand) from a local quarry was used as a fine aggregate. Similarly from the same source coarse aggregates were obtained and used in the experiment. Both fine aggregate and coarse aggregate were tested for its properties as per IS: 383 . In order to reduce the water content in the mix, a suitable superplasticizer was recommended. Clean and potable water as stipulated in IS: 456:2000 was used throughout the experiment. The physical properties of cement, manufactured sand, natural aggregate and light weight clay aggregate are given in Table 1 to 3 .
Table 1 Physical Properties of Cement

\begin{tabular}{|l|l|l|}
\hline Sl.No. & Characteristics & Value \\
\hline 1. & Standard consistency & 34 \\
\hline 2. & Fineness of cement & $0.5 \%$ \\
\hline 3. & Initial setting time & $35 \mathrm{~min}$ \\
\hline 4. & & 5 hours \\
\hline 5. & Final setting time & 3.07 \\
\hline
\end{tabular}

Table 2 Physical Properties of M-sand

\begin{tabular}{|l|l|l|}
\hline \multicolumn{1}{|c|}{ Sl.No. } & \multicolumn{1}{|c|}{ Description } & \multicolumn{1}{c|}{ Test results } \\
\hline 1. & Water absorption $\%$ & $2.80 \%$ \\
\hline 2. & Specific gravity & 2.68 \\
\hline 3. & Sieve size & $\%$ passing \\
\hline 4. & $10 \mathrm{~mm}$ & 100 \\
\hline 5. & $4.75 \mathrm{~mm}$ & 98.9 \\
\hline 6. & $2.36 \mathrm{~mm}$ & 81.5 \\
\hline 7. & $1.18 \mathrm{~mm}$ & 54.3 \\
\hline 8. & $0.6 \mathrm{~mm}$ & 34.9 \\
\hline 9. & $0.3 \mathrm{~mm}$ & 18.2 \\
\hline 10. & $0.150 \mathrm{~mm}$ & 6.9 \\
\hline 11. & $0.075 \mathrm{~mm}$ & 0 \\
\hline
\end{tabular}

Table 3 Physical Properties of Natural Aggregate and Light Weight Aggregate

\begin{tabular}{|l|l|l|}
\hline Description & Natural aggregate & $\begin{array}{l}\text { Light weight aggre- } \\
\text { gate }\end{array}$ \\
\hline $\begin{array}{l}\text { Specific } \\
\text { Gravity }\end{array}$ & 2.76 & 1.59 \\
\hline $\begin{array}{l}\text { Water absorption, } \\
\%\end{array}$ & 0.5 & 20 \\
\hline Bulk density, $\mathrm{kg} / \mathrm{m}^{3}$ & 1450 & 560 \\
\hline
\end{tabular}

\section{Mix Design}

A concrete mix can be designed by any rational method. However a most common method is by absolute volume method which is specified in IS10262:2009. While proportioning the mix certain stipulations are considered. They are the cement content, maximum water cement ratio, workability, exposure condition and degree of supervision. Further certain physical properties such as specific gravity, water absorption; moisture content, particle size, etc are needed. Similar method is followed for designing concrete mixes with light weight clay aggregate.

A typical mix proportion of normal concrete and light weight aggregate concrete are shown in Table 4. 
Table 4: Mix proportion of Normal Concrete and LWA Concrete

\begin{tabular}{|l|c|c|}
\hline \multirow{2}{*}{ Description } & $\begin{array}{c}\text { Light weight } \\
\text { concrete }\end{array}$ & $\begin{array}{c}\text { Conventional con- } \\
\text { crete }\end{array}$ \\
\cline { 2 - 3 } & \multicolumn{2}{|c|}{ Quantity (Kg/m ${ }^{3)}$} \\
\hline Cement, OPC 53 Grade & 489 & 489 \\
\hline Crusher sand & 887 & 904 \\
\hline LWA aggregate & 467 & - \\
\hline Natural aggregate & - & 793 \\
\hline Water & 170 & 220 \\
\hline w/c ratio & 0.35 & 0.45 \\
\hline
\end{tabular}

\subsection{Fresh Concrete}

The fresh concrete was prepared similar to conventional concrete. The time of mixing was about $2 \mathrm{mts}$ in order to absorb water by the light weight aggregates. In fresh concrete density, slump was determined. The slump was kept in the range of $80-100 \mathrm{~mm}$ for both types of concrete. The mix was cohesive.

\subsection{Preparation of Test Specimens}

Test cubes of size $100 * 100 * 100 \mathrm{~mm}$ were cast for determining the compressive strength of concrete. Similarly cylinders of size $100 \mathrm{~mm}$ dia and $200 \mathrm{~mm}$ high and beams of dimensions $100 * 100 * 500 \mathrm{~mm}$ were cast for split tensile strength and flexural strength, respectively. All the specimens were cured after $24 \mathrm{hrs}$ from the time of casting under constant temperature of $27 \pm 2^{\circ} \mathrm{C}$ and relative humidity of $90-100 \%$. After 24 hours of casting specimens were demoulded and kept in tank for curing.

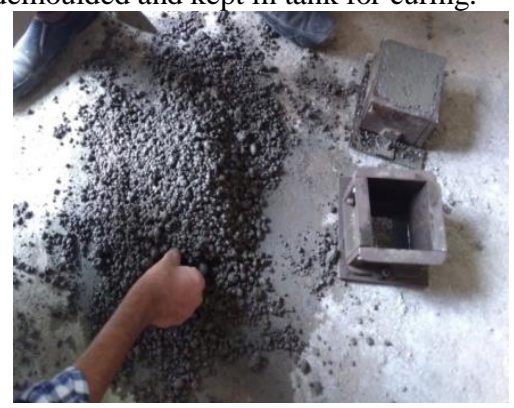

Fig 3: Mixing of concrete

\subsection{Mechanical Properties of Hardened Concrete}

The mechanical behavior of light weight concrete varies with respect to density of concrete. In case of light weight concrete, the strength parameters are much lower than the conventional concrete. However with little reduction in density, say $1800 \mathrm{~kg} / \mathrm{m}^{3}$, the strength of LWC can be compensated by reducing the w/c ratio considerably.

In order to find the efficiency of light weight concrete with light weight aggregate, a conventional concrete with natural aggregate was also cast. In both the cases M30 grade concrete was designed and experimented. Specimens were cast for determination of compressive strength, split tensile strength and flexural strength. Durability test such as rapid chloride permeability (RCPT) as per ASTM C1202:1990, water permeability test (WPT) as per DIN1048-part 5: 1990 were conducted in normal concrete as well as on LWC. The details of test results are given in Table 5.
Table 5: Mechanical properties of Conventional and light weight concrete

\begin{tabular}{|l|l|l|}
\hline Description & $\begin{array}{l}\text { Conventional con- } \\
\text { crete }\end{array}$ & $\begin{array}{l}\text { Light weight con- } \\
\text { crete }\end{array}$ \\
$\begin{array}{l}\text { Compressive strength, } \\
\left(\mathrm{N} / \mathrm{mm}^{2}\right)\end{array}$ & 44.20 & 45 \\
\hline $\mathrm{WPT},(\mathrm{mm})$ & 20 & 56 \\
\hline $\mathrm{RCPT},(\mathrm{coulombs})$ & 1680 & 2025 \\
\hline $\begin{array}{l}\text { Flexural strength, } \\
\left(\mathrm{N} / \mathrm{mm}^{2}\right)\end{array}$ & 5.43 & 4.22 \\
\hline $\begin{array}{l}\text { Split tensile strength, } \\
\left(\mathrm{N} / \mathrm{mm}^{2}\right)\end{array}$ & 4.41 & 4.11 \\
\hline
\end{tabular}

\section{Test Results and Discussion}

\subsection{Compressive Strength Test}

$100 \mathrm{mmx} 100 \mathrm{mmx} 100 \mathrm{~mm}$ cubes were casted for carrying out compression strength test, 7 day, 14 day and 28 day strength of the specimens were measured.The specimens were tested on a universal testing machine with capacity of $2000 \mathrm{kN}$.

To determine the compressive strength, we cast cubes with LECA, and by varying w/c ratio and by adding different percentage of super plasticizer. After casting and curing, the specimens are tested at 7, 14 and 28 days at UTM as per IS. 516-1959. The compressive strength results are given in the Table 6, 7 and 8. Fig.4 shows the compressive strength of all the mixes.

Table 6: Compression strength test for conventional concrete

\begin{tabular}{|l|l|l|}
\hline Day of testing & Weight of cubes $\mathbf{( k g )}$ & $\begin{array}{l}\text { Compressive strength } \\
\left(\mathbf{N} / \mathbf{m m}^{2}\right)\end{array}$ \\
\hline 7th day test & 2.536 & 29.2 \\
\hline 14th day test & 2.602 & 40 \\
\hline 28th day test & 2.690 & 44.2 \\
\hline
\end{tabular}

Table 7: Compression strength test for concrete replacing coarse aggregate by clay aggregate

\begin{tabular}{|l|l|l|l|c|}
\hline $\begin{array}{l}\text { Day of } \\
\text { testing }\end{array}$ & $\begin{array}{l}\text { Cube } \\
\text { nos }\end{array}$ & $\begin{array}{l}\text { Weight } \\
\text { of cubes } \\
(\mathbf{k g})\end{array}$ & $\begin{array}{l}\text { Compressive } \\
\text { strength } \\
\left(\mathbf{N} / \mathbf{m m}^{2}\right)\end{array}$ & $\begin{array}{l}\text { Average com- } \\
\text { pressive } \\
\text { strength } \\
\left(\mathbf{N} / \mathbf{m m}^{\mathbf{2}}\right)\end{array}$ \\
\hline \multirow{2}{*}{$\begin{array}{l}\text { 7th day } \\
\text { test }\end{array}$} & 1 & 1.962 & 23.4 & \multirow{2}{*}{20.43} \\
\cline { 2 - 4 } & 2 & 2.016 & 20.0 & \\
\cline { 2 - 4 } & 3 & 1.984 & 17.9 & \\
\hline
\end{tabular}

Table 8: Compression strength test for concrete replacing coarse aggregate by clay aggregate and by adding super plasticizer

\begin{tabular}{|c|l|l|l|c|}
\hline $\begin{array}{c}\text { Day of } \\
\text { testing }\end{array}$ & $\begin{array}{l}\text { Cube } \\
\text { nos }\end{array}$ & $\begin{array}{l}\text { Weight } \\
\text { of cubes } \\
(\mathbf{k g})\end{array}$ & $\begin{array}{l}\text { Compressive } \\
\text { strength } \\
\left(\mathbf{N} / \mathbf{m m}^{2}\right)\end{array}$ & $\begin{array}{l}\text { Average com- } \\
\text { pressive } \\
\text { strength } \\
\left(\mathbf{N} / \mathbf{m m}^{2}\right)\end{array}$ \\
\hline \multirow{2}{*}{$\begin{array}{c}\text { 7th day } \\
\text { test }\end{array}$} & 1 & 1.962 & 21.4 & \\
\cline { 2 - 4 } & 2 & 1.992 & 31.0 & \\
\cline { 2 - 4 } & 3 & 2.008 & 34.6 & \\
\hline
\end{tabular}

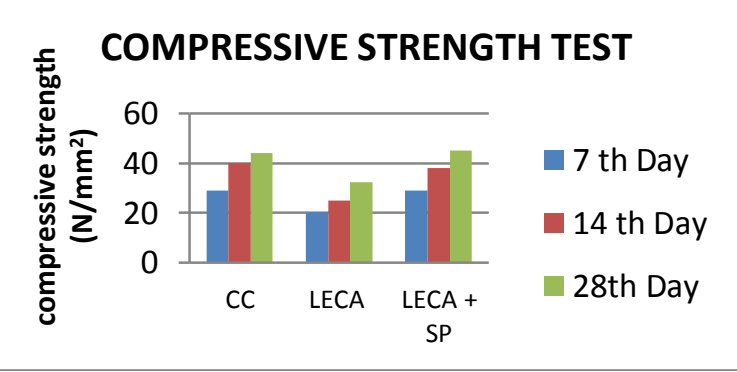

Fig 4: Compressive strength of control and LECA mixes 


\subsection{Split Tensile Strength Test}

The split tension test was conducted on cylinder specimen of $100 \mathrm{~mm}$ diameter and $200 \mathrm{~mm}$ height. The cylinders are cast, cured and tested by placing the cylinder horizontally in universal testing machine. The split tensile strength is determined at 7 th and 28th day are shown in Table 9 and Fig.5.

Table 9: Split tensile strength result

\begin{tabular}{|l|l|l|}
\hline \multirow{2}{*}{ Cylinder specimens } & \multicolumn{2}{|c|}{ Split tensile strength (N/mm2) } \\
\cline { 2 - 3 } & 7th day & 28th day \\
\hline Conventional & 2.66 & 4.42 \\
\hline $\begin{array}{l}\text { Replaced by clay aggregate by } \\
\text { adding SP }\end{array}$ & 2.56 & 4.12 \\
\hline
\end{tabular}

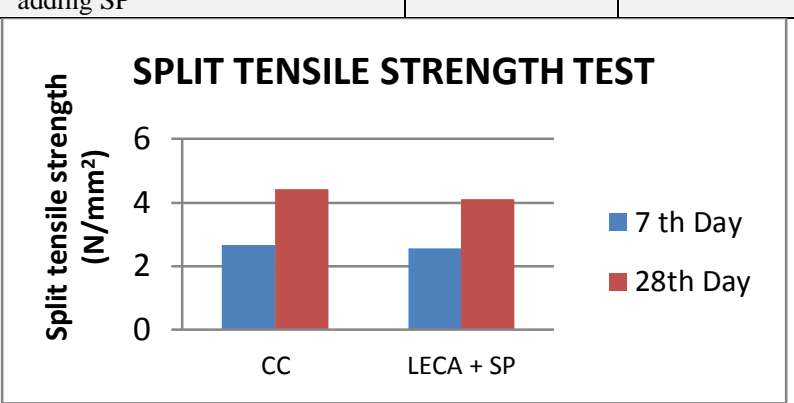

Fig.5: Graph showing Split tensile strength results

\subsection{Flexural Strength Test}

The beam of dimensions $100 \mathrm{mmx} 100 \mathrm{~mm} \times 500 \mathrm{~mm}$ has been cast to determine the flexure strength .The beam after curing has been surface dried and the points to be loaded has been marked at a distance of $L / 3$. The marked specimen has been placed on the universal testing machine and two point loading has been applied. The load at which the beam cracks has been noted. The distance of the crack from the centre point is also measured. Table 10 presents the flexural strength of conventional and LWC mixes.

Table 10: Flexure strength result

\begin{tabular}{|c|c|}
\hline Beam specimens & $\begin{array}{l}\text { Flexural strength }\left(\mathrm{N} / \mathrm{mm}^{2}\right)(28 \text { th } \\
\text { day) }\end{array}$ \\
\hline Conventional concrete & 5.43 \\
\hline $\begin{array}{l}\text { Replaced by clay aggregate by } \\
\text { adding SP }\end{array}$ & 4.28 \\
\hline
\end{tabular}

It was found that the compressive strength of normal concrete and LWC are observed to be similar by reduction in w/c ratio. However permeability of water in LWC is doubled compared to normal concrete. Though Chloride diffusion into LWC is higher than normal concrete, it is well within the good grade concrete. Considering the mechanical properties, the flexural and split tensile strengths are in agreement with IS code of practice. The flexural strength of LWC is lower than normal concrete.

\subsection{Durability Test}

\subsubsection{Rapid Chloride Permeability Test (RCPT):}

The objective of this test is to determine the chloride penetration resistance of concrete specimens at 28 days through rapid chloride permeability test. Test results are shown in Table 11.

Table 11: RCPT results

\begin{tabular}{|l|c|c|}
\hline \multirow{2}{*}{$\begin{array}{l}\text { Total charge (Coulombs) } \\
\text { passed through concrete }\end{array}$} & $\begin{array}{c}\text { Conventional } \\
\text { Concrete }\end{array}$ & LECA \\
\cline { 2 - 3 } & 1674 & 2025 \\
\hline
\end{tabular}

\subsubsection{Water Permeability Test (WPT):}

The test is carried out according to German Standard DIN 1048 on concrete specimens of size $150 \times 150 \times 150 \mathrm{~mm}$, at an age of 28 days. The test cell assembly being used had the provision for testing six cubes at a time.
Once the specimens were assembled in the test cells, a water pressure of $500 \mathrm{KPa}$ ( 5 bar) was applied for 72 hours. Water pressure is applied by means of an arrangement consisting of a water tank connected to an air compressor through a valve, to adjust the pressure. Table 12 presents the WPT results of conventional and LWC mixes.

Table 12: WPT results

\begin{tabular}{|l|l|}
\hline Cubical specimen & Depth of penetration in $\mathbf{~ m m}$ \\
\hline $\begin{array}{l}\text { Renventional } \\
\text { adding sp }\end{array}$ & 20 \\
\hline
\end{tabular}

\section{Conclusion}

Light weight concrete can also be produced equivalent to normal concrete without increasing the cement content.

Since it satisfies the compressive strength criteria it can be recommended for structural grade concrete.

It also fulfills durability parameters.

Light weight concrete can substantially reduce the dead weight of the structure by $33 \%$.

Thus, LECA can be used in order to reduce the self weight and also freezing and thawing effects in the pavements can be reduced. Pavement tests such as Dynamic Cone Penetrometer test has to be evaluated in future.

\section{References}

[1] Pramod B. slagar\& P.S Patel," Development of Innovative Structural Light Weight Concrete by using Expanded Clay aggregates"RITSakharala, Maharastra, Journal of civil and architectural engineering, Vol2, issue 1, 2017.

[2] IS :9142- 1979 (Reaffirmed 2002) Indian standard specification for artificial light weight aggregates for concrete masonry units (first reprint October 1990).

[3] Serkensubasi, " The effects of using flyash on high strength light weight concrete produced with expanded clay aggregate",scientific research and essay, Vol 4, www.academic journals.org.

[4] Serkensubasi, " The effects of using flyash on high strength light weight concrete produced with expanded clay aggregate",scientific research and essay, Vol 4, www.academic journals.org.

[5] ACI 318-14, "Building code requirements for structural concrete"

[6] IS:4031, "Method of physical test for hydraulic cement",Bureau of indian standards, Manakbhavan, New Delhi.

[7] IS :383:2016, "Coarse and fine aggregate for concrete - specification ", Bureau of Indian standards ,Manakbhavan, New Delhi.

[8] IS:456:2000,'Plain and reinforced concrete - Code of practice “, Bureau of Indian Standards, Manakbhavan, New Delhi. 